\title{
Growth partitioning within beech trees (Fagus sylvatica L.) varies in response to summer heat waves and related droughts
}

\author{
Nicolas Latte $^{1} \cdot$ François Lebourgeois $^{2,3} \cdot$ Hugues Claessens $^{1}$
}

Received: 13 March 2015/Revised: 31 August 2015/Accepted: 4 September 2015/Published online: 24 September 2015

(C) Springer-Verlag Berlin Heidelberg 2015

\begin{abstract}
Key message Beech growth variability and climate sensitivity are much higher in the crown top than in the bole. The most notable bole-crown discrepancies occurred in response to extreme climate conditions.

Abstract To characterize growth partitioning within the tree and its responses to climate, we studied eight dominant beech trees (Fagus sylvatica L.) of a pure, even-aged 98 -year-old stand in Belgium. We sampled ten disks along the stem from breast height to treetop and examined the inter-annual patterns of, and discrepancies between, ringarea and volume increments by performing detailed stem analysis and dendroecological investigations. Although the common inter-annual variation among all increment series was high, we observed increasing growth variability and climate sensitivity with height, leading to notable bolecrown discrepancies. Both the common inter-annual variation and bole-crown discrepancies were mainly driven by
\end{abstract}

Communicated by T. Kajimoto.

Electronic supplementary material The online version of this article (doi:10.1007/s00468-015-1288-y) contains supplementary material, which is available to authorized users.

Nicolas Latte

nicolas.latte@ulg.ac.be

1 Forest Resources Management, University of Liège, Gembloux Agro-Bio Tech, Passage des Déportés 2, 5030 Gembloux, Belgium

2 UMR1092, Laboratoire d'Étude des Ressources Forêt Bois (LERFoB), AgroParisTech, Rue Girardet 14, 54042 Nancy, France

3 INRA, UMR1092, Laboratoire d'Étude des Ressources ForêtBois (LERFoB), Centre INRA de Nancy, 54280 Champenoux, France summer heat waves and related droughts of the previous year, and spring droughts of the current year. Despite these discrepancies, the radial growth at breast height can be considered a good estimate of the tree volume increment but not for the purpose of focusing on climatic effects of isolated years. Extreme climatic conditions increase the risk of inaccurate estimations. The results of the present study are discussed in relation to tree ecophysiology hypotheses.

Keywords Tree-ring analysis · Growth allocation . Climate sensitivity - Stem analysis - Reserve depletion . Masting trade-off

\section{Introduction}

For dendrochronological investigation, tree-ring sampling is traditionally performed at breast height $(1.3 \mathrm{~m}$ aboveground) mainly due to its operational simplicity and connection with conventional forest DBH measurements (Schweingruber 1996). Despite the fact that radial growth varies at different levels along the bole, sampling at breast height is considered an ideal balance of homogenous growth while maintaining long chronosequences (Chhin and Wang 2005). In consequence, an underlying assumption of most tree-ring studies is that the growth at breast height is an unbiased estimate of whole tree growth variations and patterns, or at least, that the responses to climate and other environmental factors are sufficiently close to extend results and related interpretations to the whole tree. However, the small number of studies devoted to test this hypothesis did not confirm its validity for both conifers (Bouriaud et al. 2005a; Chhin and Wang 2005; Chhin et al. 2010; Kerhoulas and Kane 2012; Sohn et al. 2012; van der Maaten-Theunissen and Bouriaud 2012) and broadleaved 


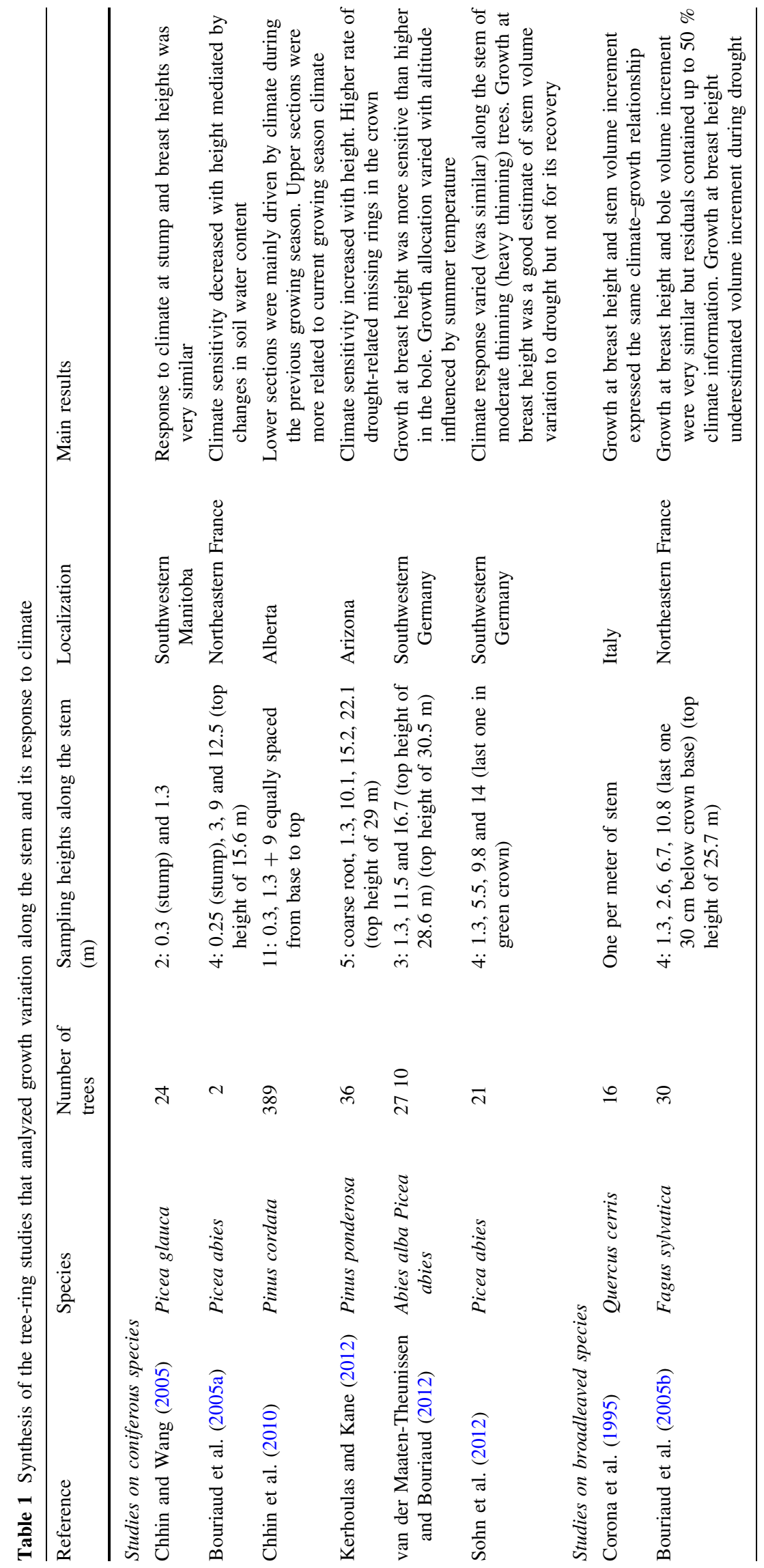


trees (Corona et al. 1995; Bouriaud et al. 2005b; synthesis in Table 1).

Most previous studies agree that comparable information on growth can be obtained from different sampling levels along the tree stem. However, the reported changes in the climate-growth relationship are not consistent among studies. The most influential climate variables can remain the same along the stem, with decreasing (Bouriaud et al. 2005a; van der Maaten-Theunissen and Bouriaud 2012) or increasing (Kerhoulas and Kane 2012) climate sensitivity with height, or can differ between stem base and crown (Chhin et al. 2010). The radial growth at breast height and stem volume increment have been shown to express similar patterns (Corona et al. 1995; Hogg et al. 2005, Kerhoulas and Kane 2012), but discrepancies were observed in response to stressful growing conditions (Bouriaud et al. 2005b) and thereafter, during growth recovery (Sohn et al. 2012). The differences in sampling protocol among studies complicate comparisons and may lead to misunderstanding. For instance, the term "stem" was either defined as the bole (part of the stem below the crown base) or as the whole stem (from the base to the top of the tree). Therefore, there is still uncertainty about the effect of sampling height on dendroecological investigations.

Growth partitioning within the tree depends on ecophysiological processes that are influenced by intrinsic and extrinsic factors. Due to differences in phenology, growth allometry, and sensitivity to competition, angiosperm and coniferous tree species use different ecophysiological strategies and responses to climate variation (Way and Oren 2010; Carnicer et al. 2013). For a given species, the stem form and taper can vary strongly among individuals and can be influenced by age (Barbaroux et al. 2003; Genet et al. 2009), altitude and climate (DeLucia et al. 2000; van der Maaten-Theunissen and Bouriaud 2012), and stand density and silviculture (Sohn et al. 2012). Furthermore, studies on carbon balance and allocation showed connections between seasonal and spatial patterns of respiration and photosynthesis, and variations in biomass increments along the stem (Lebaube et al. 2000; Ceschia et al. 2002; Le Goff et al. 2004). In the context of increasing climate variability (IPCC 2012), there is a rising need for evaluating the impact of climatic conditions and particularly of extreme events on these physiological processes (Campioli et al. 2013; Carnicer et al. 2013).

The aims of the present study were to (1) characterize the growth partitioning along the stem and between tree compartments (bole, crown, and whole stem), and its responses to climate, especially to extreme climatic conditions that induce physiological disorders and notable growth reductions, and (2) evaluate to what extent the radial growth at breast height - the dendrochronological standard-is representative of the tree volume increment. Major discrepancies between these two measurements could demonstrate important inaccuracies in tree volume and increment, as most allometric equations were developed from $\mathrm{DBH}$ (Zianis et al. 2005; Muukkonen 2007). European beech (Fagus sylvatica L.) was selected for its ecological and economic importance in Europe and because it has been the focus of numerous dendrochronological and ecophysiological studies (Geßler et al. 2007). Contrary to previous studies (Table 1), we accounted for the fact that during the lifespan of the tree, a given height may be part of different tree compartments (e.g., from crown to bole), and included the volume increment of the branches as their volume is not negligible for broadleaved species.

\section{Materials and methods}

\section{Study area}

The study was conducted in the Ardenne ecoregion (southern Belgium) included in the temperate oceanic bioclimatic zone of Europe (Lindner et al. 2010). Between 1980 and 2012, annual rainfall and temperature were $1152 \mathrm{~mm}$ and $7.7^{\circ} \mathrm{C}$, respectively. The sampled trees were selected in a pure evenaged 98-year-old medio-European acidophilus beech forest (CORINE classification 41.111; $50.03 \mathrm{~N} 5.49 \mathrm{E}, 549 \mathrm{~m}$

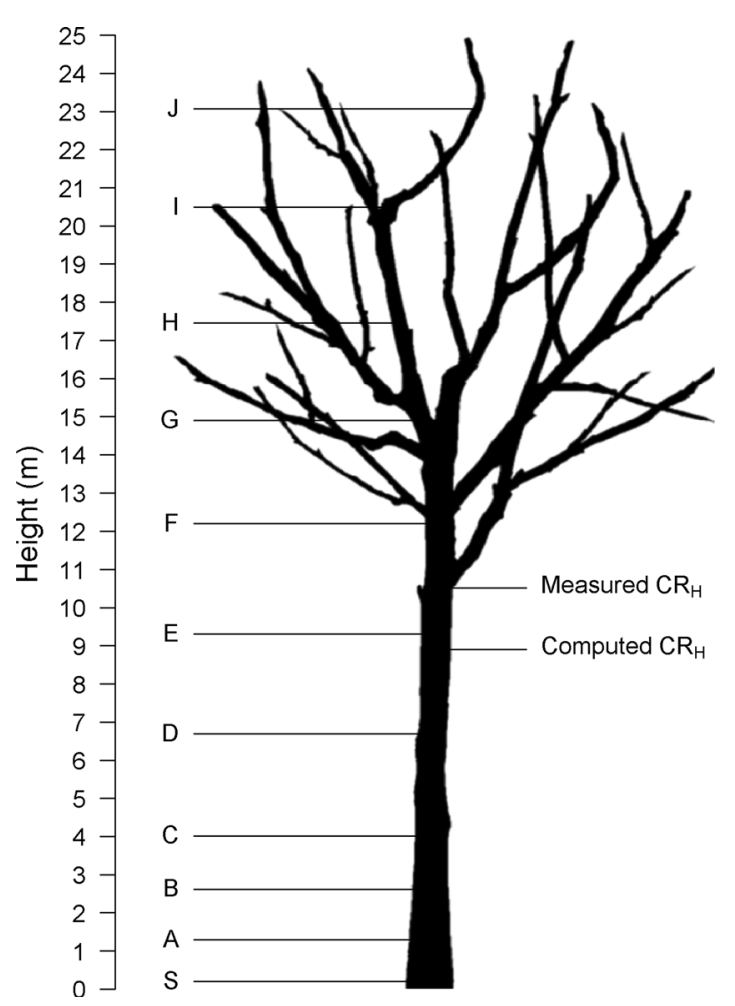

Fig. 1 Illustration of ten sampling heights, from cross-sections $A$ to $J$, along the whole main stem of the tree (average values of the eight beech trees). Disks were collected in 2012. $S$ stump height, $C R_{H}$ crown base height in 2012 
Table 2 Chronology statistics of raw and detrended ring-area increment (RAI) and volume increment (VI) series for the common period 1982-2012

\begin{tabular}{|c|c|c|c|c|c|c|c|c|c|}
\hline \multirow[t]{2}{*}{ Disk } & \multirow{2}{*}{$\begin{array}{l}\text { Mean height } \\
(\min -\max )(\mathrm{m})\end{array}$} & \multicolumn{4}{|c|}{ Raw RAI series $\left(\mathrm{cm}^{2}\right.$ year $\left.{ }^{-1}\right)$} & \multicolumn{4}{|c|}{ Detrended RAI series } \\
\hline & & Mean & $\begin{array}{l}\text { Standard } \\
\text { deviation }\end{array}$ & $\begin{array}{l}\text { Correlation } \\
\text { with } A\end{array}$ & $\begin{array}{l}\text { Correlation } \\
\text { with TR }\end{array}$ & $\begin{array}{l}\text { Effective } \\
\text { signal (ES) }\end{array}$ & $\begin{array}{l}\text { Expressed } \\
\text { population signal } \\
\text { (EPS) }\end{array}$ & $\begin{array}{l}\text { Mean } \\
\text { sensitivity } \\
\text { (MS) }\end{array}$ & $\begin{array}{l}\text { Gini } \\
\text { coefficien } \\
(\mathrm{GC})\end{array}$ \\
\hline$A$ & 1.3 & 16.5 & 6.1 & 1.00 & 0.93 & 0.56 & 0.91 & 0.31 & 0.14 \\
\hline$B$ & $2.6(2.4-2.7)$ & 15.9 & 5.6 & 0.97 & 0.96 & 0.59 & 0.92 & 0.29 & 0.14 \\
\hline$C$ & $4(3.8-4.2)$ & 14.2 & 5.3 & 0.98 & 0.95 & 0.56 & 0.91 & 0.29 & 0.14 \\
\hline$D$ & $6.7(6.4-7.1)$ & 12.7 & 4.7 & 0.97 & 0.97 & 0.58 & 0.92 & 0.28 & 0.14 \\
\hline$E$ & $9.4(8.9-10)$ & 11.9 & 4.0 & 0.91 & 0.96 & 0.63 & 0.93 & 0.27 & 0.13 \\
\hline$F$ & $12.3(11.5-12.8)$ & 9.3 & 3.0 & 0.83 & 0.94 & 0.65 & 0.94 & 0.28 & 0.14 \\
\hline$G$ & $15(14-15.8)$ & 8.4 & 2.7 & 0.79 & 0.91 & 0.64 & 0.94 & 0.29 & 0.14 \\
\hline$H$ & $17.6(16.4-18.5)$ & 6.1 & 2.1 & 0.72 & 0.88 & 0.68 & 0.94 & 0.31 & 0.15 \\
\hline I & $20.7(19.1-21.7)$ & 2.4 & 0.9 & 0.57 & 0.77 & 0.67 & 0.94 & 0.37 & 0.17 \\
\hline$J$ & $23.3(21.6-24.3)$ & 0.8 & 0.3 & 0.41 & 0.62 & 0.63 & 0.93 & 0.39 & 0.18 \\
\hline \multirow{2}{*}{\multicolumn{2}{|c|}{ Wood compartment }} & \multicolumn{4}{|c|}{ Raw VI series $\left(\mathrm{dm}^{3}\right.$ year $\left.^{-1}\right)$} & \multicolumn{4}{|c|}{ Detrended VI series } \\
\hline & & Mean & $\begin{array}{l}\text { Standard } \\
\text { deviation }\end{array}$ & $\begin{array}{l}\text { Correlation } \\
\text { with } A\end{array}$ & $\begin{array}{l}\text { Correlation } \\
\text { with TR }\end{array}$ & $\begin{array}{l}\text { Effective } \\
\text { signal (ES) }\end{array}$ & $\begin{array}{l}\text { Expressed } \\
\text { population signal } \\
\text { (EPS) }\end{array}$ & $\begin{array}{l}\text { Mean } \\
\text { sensitivity } \\
\text { (MS) }\end{array}$ & $\begin{array}{l}\text { Gini } \\
\text { coefficien } \\
\text { (GC) }\end{array}$ \\
\hline ST & Whole stem & 25.6 & 8.6 & 0.96 & 0.99 & 0.71 & 0.95 & 0.28 & 0.13 \\
\hline LS & Lower stem & 16.2 & 6.0 & 0.99 & 0.96 & 0.65 & 0.94 & 0.29 & 0.13 \\
\hline US & Upper stem & 9.4 & 3.1 & 0.78 & 0.9 & 0.71 & 0.95 & 0.28 & 0.14 \\
\hline $\mathrm{BR}$ & Branches & 6.9 & 2.6 & 0.84 & 0.97 & 0.72 & 0.95 & 0.28 & 0.14 \\
\hline $\mathrm{CR}$ & Crown & 15.7 & 5.8 & 0.80 & 0.94 & 0.72 & 0.95 & 0.28 & 0.14 \\
\hline TR & Tree & 31.9 & 11.5 & 0.93 & 1.00 & 0.72 & 0.95 & 0.28 & 0.14 \\
\hline
\end{tabular}

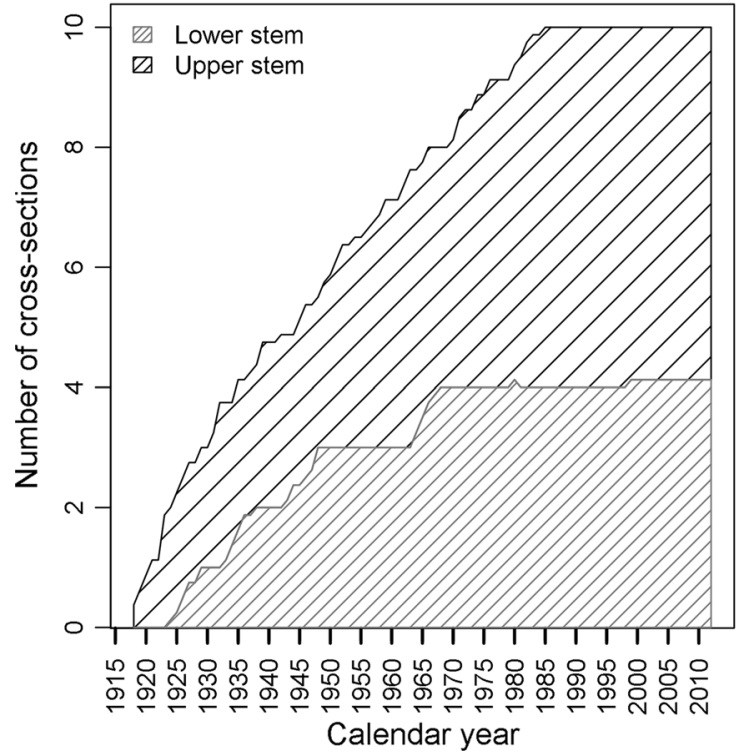

Fig. 2 Both plots refer to average values of the eight selected beech trees. Left number of cross-sections used to compute volume increments (VI) of the lower stem ( $\mathrm{LS}_{\mathrm{VI}}$; i.e., below crown base height), upper stem (US $\mathrm{VII}_{\mathrm{VI}}$; i.e., above crow base height) and whole

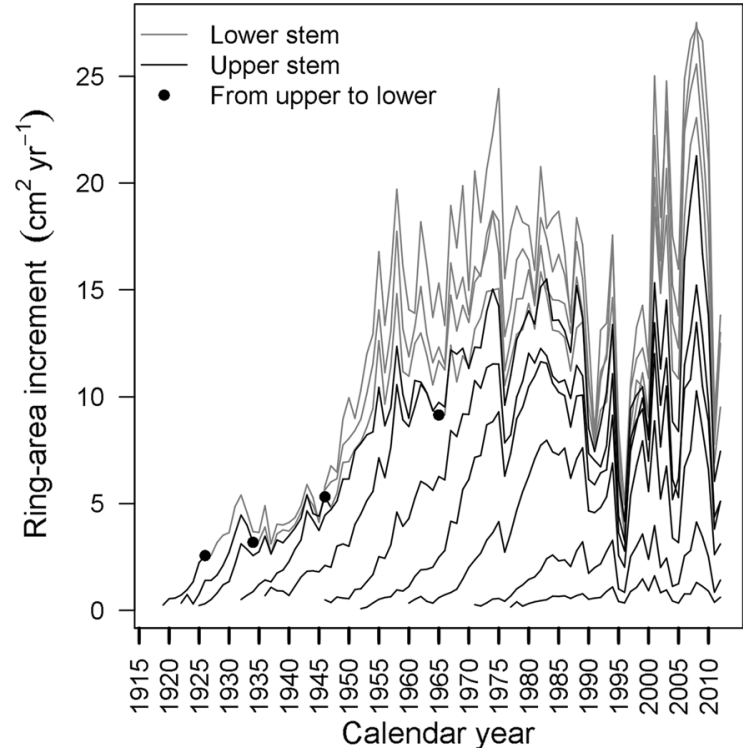

stem $\left(\mathrm{ST}_{\mathrm{VI}}=\mathrm{LS}_{\mathrm{VI}}+\mathrm{US}_{\mathrm{VI}}\right)$. Right ring-area increments $(\mathrm{RAI})$ at the 10 sampling heights $\left(A_{\mathrm{RAI}}-J_{\mathrm{RAI}}\right)$. Black points indicate when a crosssection moved from upper stem to lower stem 
a.s.1.). The well-drained brown soil (WRB soil classification, depth $=90 \mathrm{~cm}$ ) fit well with beech requirements (Weissen et al. 1994). Stand density, basal area, mean DBH, and dominant height were 227 stems ha $\mathrm{ha}^{-1} 22.9 \mathrm{~m}^{2} \mathrm{ha}^{-1}$, $35.2 \mathrm{~cm}$, and $25.6 \mathrm{~m}$, respectively, corresponding to the second yield class described by Schober (1995).

\section{Tree sampling and ring-width measurements}

In the winter of 2012-2013, eight dominant or co-dominant and healthy beech trees of comparable dimensions were sampled for stem analysis (mean $\mathrm{DBH}=40.4 \mathrm{~cm}$, mean height $=25.2 \mathrm{~m}$; supplementary material: Table $\mathrm{A})$. The selected trees were felled and ten disks per tree $(A, B, C$, $\ldots, J)$ were sawed along the main stem from the breast height to the top of the tree (Fig. 1; Table 2). In cases of forked stems, we selected the path with the largest crosssections, the closest to the vertical axis of the tree, and ending in the center of the crown top. The eight disks $C-$ $J$ were equally spaced from breast height $(A)$ to the tip of the main stem. Disk $B$ was located at mid-length between $A$ and $C$. When necessary, disk locations were slightly shifted to avoid potential anomalous growth due to branch junctions, reaction wood, or other irregularities.

Air-dried disks were planed, progressively sanded with finer grits of sandpaper (up to 240), and scanned at high resolution (1200 dpi). Tree-ring widths were measured on each disk along three radii (three-pointed star) from the pith to the bark with an accuracy of 1/100 mm using WINDENDRO (Regent Instruments Canada Inc. 2009). Individual ring-width series were carefully cross-dated by progressively detecting the regional pointer years (Penninckx et al. 1999; Kint et al. 2012; Latte et al. 2015). The ring-width series were converted into ring-area increments (RAI, Fig. 2; RAI at breast height corresponding to basal area increment) for a more accurate quantification of wood production (Bouriaud et al. 2005b; Hogg et al. 2005; Weber et al. 2013) and then averaged by cross-section and tree.

\section{Computation of volume increments}

The volume increments of the wood compartments of each tree were computed in $\mathrm{R}$ ( $\mathrm{R}$ Core Team 2012) using the function "stemanalysis" of the package "treeglia" (Bascietto and Scarascia-Mugnozza 2004) and species-specific allometric equations of Dagnelie et al. (2013). Dagnelie's equations were developed from 1043 beeches of southern Belgium (58\% from the Ardenne ecoregion; 19-265 years old). The function "stemanalysis" interpolates past annual tree heights between cross-sections using Carmean's algorithm, and estimates annual volumes using Smalian's formula for the logs and the cone formula for the tip (i.e., part of the main stem above cross-section $J$; Fig. 1).
The volume increment of the whole main stem $\left(\mathrm{ST}_{\mathrm{VI}}\right)$ was computed using the function "stemanalysis". The volume increment below the cross-section $A$ was included by simulating a stump level cross-section (Fig. 1) using Eq. (1) (Dagnelie et al. 2013; supplementary material: Fig. A).

$S_{\mathrm{D}_{k, i}}=\frac{A_{\mathrm{D}_{k, i}}^{1.213}}{1.578}$

$S_{\mathrm{D}}(\mathrm{cm})$ denotes the diameter at stump height $(0.2 \mathrm{~m}), A_{\mathrm{D}}$ (cm) denotes the diameter at breast height, and $k$ and $i$ denote the tree and the year, respectively.

The volume increments of the lower part of the stem (LS $S_{\mathrm{VI}}$, i.e., below the crown base height) and the upper part of the stem (US $\mathrm{VI}_{\mathrm{VI}}$; i.e., above the crown base height) were computed using the "stemanalysis" function and the crown base height $\left(\mathrm{CR}_{\mathrm{H}}\right.$; i.e., insertion of first primary green branch) estimated using Eq. (2) (supplementary material: Fig. B). During the lifespan of the trees, the number of cross-sections used to compute these two volume increments increased and four cross-sections $(A-D)$ moved from the upper stem to the lower stem (Fig. 2).

$$
\begin{aligned}
\mathrm{CR}_{\mathrm{H}_{k, i}} & =\mathrm{TR}_{\mathrm{H}_{k, i}} \times\left(1-R_{\mathrm{D}_{k, i}}\right) \\
& =\mathrm{TR}_{\mathrm{H}_{k, i}} \times\left(1-\frac{\mathrm{CR}_{\mathrm{L}_{k, i}}}{\mathrm{TR}_{\mathrm{H}_{k, i}}}\right)=\mathrm{TR}_{\mathrm{H}_{k, i}}-\mathrm{CR}_{\mathrm{L}_{k, i}}
\end{aligned}
$$

$\mathrm{CR}_{\mathrm{H}}(\mathrm{m})$ denotes the crown base height, $\mathrm{TR}_{\mathrm{H}}(\mathrm{m})$ denotes the tree top height, $R_{\mathrm{D}}$ denotes the ratio of crown length to tree height (Dagnelie et al. 2013; equation with DBH as independent variable), $\mathrm{CR}_{\mathrm{L}}(\mathrm{m})$ denotes the crown length, and $k$ and $i$ denote the tree and the year, respectively.

The volume increment of the crown $\left(\mathrm{CR}_{\mathrm{VI}}\right)$ was estimated by expanding $\mathrm{US}_{\mathrm{VI}}$ using Eq. (3).

$\mathrm{CR}_{\mathrm{VI}_{k, i}}=\mathrm{US}_{\mathrm{VI}_{k, i}} \times \mathrm{EF}_{k, i}=\mathrm{US}_{\mathrm{VI}_{k, i}} \times \frac{\left(\mathrm{TR}_{\mathrm{DV}_{k, i}}-\mathrm{LS}_{\mathrm{DV}_{k, i}}\right)}{\left(\mathrm{ST}_{\mathrm{DV}_{k, i}}-\mathrm{LS}_{\mathrm{DV}_{k, i}}\right)}$

$\mathrm{CR}_{\mathrm{VI}}\left(\mathrm{dm}^{3}\right.$ year $\left.^{-1}\right)$ denotes the crown volume increment, $\mathrm{LS}_{\mathrm{VI}}\left(\mathrm{dm}^{3}\right.$ year $\left.^{-1}\right)$ denotes the lower stem volume increment, EF denotes the expansion factor (supplementary material: Fig. C), $\mathrm{TR}_{\mathrm{DV}}, \mathrm{ST}_{\mathrm{DV}}$ and $\mathrm{US}_{\mathrm{DV}}\left(\mathrm{dm}^{3}\right)$ denotes the tree, whole stem and upper stem Dagnelie's volumes, respectively (Dagnelie et al. 2013; equations with DBH and $\mathrm{TR}_{\mathrm{H}}$ as independent variables), and $k$ and $i$ denote the tree and the year, respectively.

The volume increment of (the aboveground part of) the tree $\left(\mathrm{TR}_{\mathrm{VI}}\right)$ was computed by summing $\mathrm{ST}_{\mathrm{VI}}$ and $\mathrm{CR}_{\mathrm{VI}}$. The volume increment of the branches $\left(\mathrm{BR}_{\mathrm{VI}}\right)$ was computed by subtracting $\mathrm{CR}_{\mathrm{VI}}$ and $\mathrm{US}_{\mathrm{VI}}$.

$\mathrm{ST}_{\mathrm{VI}}$ was accurately computed using stem analysis and Eq. (1). However, two sources of imprecision should be noted. Firstly, the computed $\mathrm{CR}_{\mathrm{H}}$ (Eq. 2) was, in 2012, on average $1.5 \mathrm{~m}$ lower than that measured (Fig. 1; 
supplementary material: Fig. D). $\mathrm{LS}_{\mathrm{VI}}$ was thus underestimated (and $\mathrm{US}_{\mathrm{VI}}$ overestimated) in 2012 and likely also in previous years. $\mathrm{LS}_{\mathrm{VI}}$ and $\mathrm{US}_{\mathrm{VI}}$ estimations could likely be more accurate considering stand density effects on the ratio of crown length to tree height $\left(\mathrm{R}_{\mathrm{D}}\right)$ during the whole stand development (such equations were not available). Secondly, $\mathrm{US}_{\mathrm{VI}}$ was extrapolated at the scale of the whole crown $\left(\mathrm{CR}_{\mathrm{VI}}\right)$ using Eq. (3). We thus made the assumption that $\mathrm{CR}_{\mathrm{VI}}$ was proportional to $\mathrm{US}_{\mathrm{VI}}$. As a part of the bole was included in the upper stem and extrapolated to the crown, potential bole-crown differences may be reduced.

\section{Chronology statistics and detrending}

The calculation of chronology statistics (for the common period 1982-2012) and series detrending were achieved using R (R Core Team 2012) with the package "dplR" (Bunn 2008). A cubic smoothing spline with a $50 \%$ frequency cut-off at 10 years (Bouriaud et al. 2005b; van der Maaten-Theunissen and Bouriaud 2012) was fitted to the individual cross-section ring-area increments $\left(A_{R A I}, B_{R A I}\right.$, $\left.\mathrm{C}_{\mathrm{RAI}}, \ldots, \mathrm{J}_{\mathrm{RAI}}\right)$ and wood compartment volume increments $\left(\mathrm{ST}_{\mathrm{VI}}, \mathrm{LS}_{\mathrm{VI}}, \mathrm{US}_{\mathrm{VI}}, \mathrm{BR}_{\mathrm{VI}}, \mathrm{CR}_{\mathrm{VI}}\right.$, and $\left.\mathrm{TR}_{\mathrm{VI}}\right)$ to extract longand medium-term variations, mainly due to age, competition, and silviculture (Cook and Kairiukstis 1990). Standardized indices $\left(X_{\mathrm{I}}\right.$, with $X_{\mathrm{I}}=$ one of the cross-sections or wood compartments; e.g., $A_{\mathrm{I}}$ denotes the detrended series of $A_{\mathrm{RAI}}$ ) were calculated as the ratio of observed raw values to fitted values. This detrending method maximizes the climate signal in the chronologies (Cook and Kairiukstis 1990).

The expressed population signal (EPS) and the effective signal (ES) were computed from raw series to assess overall chronology quality. The mean sensitivity (MS) was computed from detrended series to quantify the inter-annual variability. In addition to MS, the Gini coefficient (GC) was computed to integrate all possible lags in the mean sensitivity function (Biondi and Qeadan 2008).

\section{Climate data}

The climate data were accessed from the closest meteorological station, located at approximately $4.5 \mathrm{~km}$ from the beech stand (IRM Saint-Hubert Station, $560 \mathrm{~m}$ a.s.l.), which had records from 1980 to 2012 of the daily minimum and maximum temperatures $\left(T_{\min }\right.$ and $T_{\max }$ in $\left.{ }^{\circ} \mathrm{C}\right)$, precipitation $(P$ in $\mathrm{mm})$, air humidity $(\mathrm{Hu}$ in $\%)$, solar radiation ( $\mathrm{Sr}$ in $\mathrm{MJ} \mathrm{m}^{-2} \mathrm{day}^{-1}$ ), and wind speed (Ws in $\mathrm{m} \mathrm{s}^{-1}$ ). Penman's potential evapotranspiration (PET) was computed daily according to the formula in ASCE-EWRI (2005) using $T_{\min }, T_{\max }, \mathrm{Hu}, \mathrm{Sr}$, and Ws. The 882 single and multi-month climatic variables, used for climate- growth analysis, were obtained by averaging daily $T_{\min }$, $T_{\max }, \mathrm{Hu}$, and $\mathrm{Sr}$, and summing daily $P$, PET and the climatic water balance (WB $=P-$ PET) for periods from 1 to 7 month(s); the last month of these periods ranged from April of the previous year to September of the current year.

\section{Climate-growth analysis}

The ratios $A_{\mathrm{I}}: B_{\mathrm{I}}-J_{\mathrm{I}}, \mathrm{LS}_{\mathrm{I}}: \mathrm{CR}_{\mathrm{I}}, \mathrm{LS}_{\mathrm{I}}: \mathrm{US}_{\mathrm{I}}$, and $A_{\mathrm{I}}: \mathrm{TR}_{\mathrm{I}}$ were computed to highlight differences between series, and thereby growth partitioning within the trees. The detrended and ratio series of the eight beech trees were then averaged. The overall relationship between the series (Table 2) and the climatic variables was analyzed in $\mathrm{R}$ ( $\mathrm{R}$ Core Team 2012) using the sparse partial least squares (sPLS) method (package "mixOmics", formerly named "IntegrOmics"; Lê Cao et al. 2009). This method maximizes the covariance between two matrices $[Y=f(X)$ where $Y=$ growth indices and $X=$ climatic variables] and can be used when the number of $X$ is higher than the observations (i.e., number of years) and when there is multicollinearity among $X$. sPLS (single component) was computed between the series and the standardized climatic variables (i.e., mean 0 and standard deviation 1) for the period 1982-2012. The most explanatory climatic variables were pre-selected based on the variable importance in projection (VIP $\geq 1.5$ ). To identify the best subset of, at most, three of the pre-selected variables, linear regressions between the $Y$ variates (i.e., sPLS projections of $Y$ ) and the pre-selected variables were performed using the leaps algorithm (package "bestglm"; McLeod and Xu 2014) and the Bayesian information criterion (BIC). The subset variables were then used to develop one linear regression model by series. The combination of sPLS and linear regression ensured to include potential interactions among the climatic variables. Significance of the correlation coefficients was tested by the bootstrap method with a $95 \%$ confidence interval (package "bootres", recently renamed "treeclim"; Zang and Biondi 2013). The procedure was performed separately for the ring-area increment (RAI) and volume increment (VI) series, and the ratio series.

\section{Discrepancy and pointer year analysis}

We focused on the differences between detrended series: (1) $A_{\mathrm{I}}$ (the dendrochronological standard) and $J_{\mathrm{I}}$ (crown top; the least correlated with $A_{\mathrm{I}}$ and the most sensitive to climate) to evaluate the growth variation along the stem; (2) $\mathrm{LS}_{\mathrm{I}}$ and $\mathrm{CR}_{\mathrm{I}}$ to evaluate the bole-crown differences, and (3) $A_{\mathrm{I}}$ and $\mathrm{TR}_{\mathrm{I}}$ to evaluate the reliability of growth at breast height for estimating tree volume increment. The discrepancy (Dy) was computed using Eq. (4). 
$\operatorname{Dy}_{X_{\mathrm{I}}: Y_{l k, i}}=\frac{\mathrm{X}_{\mathrm{I}_{k, i}}-\mathrm{Y}_{\mathrm{I}_{k, i}}}{\mathrm{TR}_{\mathrm{I}_{k, i}}} \times 100$

$\mathrm{DY}_{X_{\mathrm{I}}: Y_{\mathrm{I}}}(\%)$ denotes the discrepancy between the two detrended series $X_{\mathrm{I}}$ (e.g., $A_{i}$ ) and $Y_{\mathrm{I}}\left(\right.$ e.g., $J_{\mathrm{I}}$ ), TR $\mathrm{I}$ denotes the detrended series of the tree volume increment, and $k$ and $i$ denote the tree and the year, respectively. The use of $\mathrm{TR}_{\mathrm{I}}$ (instead of $X_{\mathrm{I}}$ ) as denominator allows for a more robust estimate of the discrepancy.

Pointer year (PY) analysis was used to identify the years with unusual growth (low growth $=$ negative PY and high growth = positive PY) common to at least five trees using Cropper's method, as described in Neuwirth et al. (2007). Furthermore, to highlight the effect of extreme climatic conditions on growth and its variation within the tree, PYs and discrepancy years $(-10 \% \leq \mathrm{Dy} \geq 10 \%)$ were characterized in terms of unusual and/or extreme climatic events (Institut Royal Météorologique (IRM) 2000).

\section{Results}

\section{Chronology statistics and quality}

During the life span of the selected trees (1918-2012), the mean height increment was $26.5 \pm 1.7 \mathrm{~cm} \mathrm{year}^{-1}$ (mean $\pm \mathrm{SD}$ ), ring-width at breast height was $2.0 \pm$ $0.6 \mathrm{~mm}$, ring-area increment at breast height $\left(\mathrm{A}_{\mathrm{RAI}}\right)$ was $12.2 \pm 7.3 \mathrm{~cm}^{2}$ year $^{-1}$, and tree volume increment $\left(\mathrm{TR}_{\mathrm{VI}}\right)$ was $19.4 \pm 14.5 \mathrm{dm}^{3}$ year $^{-1}$. These values reflect rather good growth in the context of the Ardenne plateau

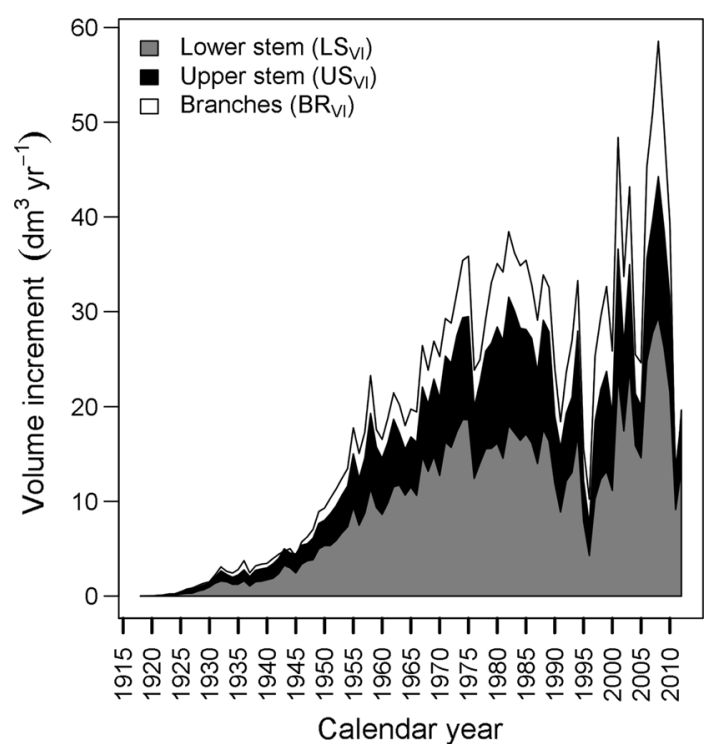

Fig. 3 Volume increments (VI; average values of the eight trees) for the period 1918-2012 of the lower stem (LS $\left.S_{V I}\right)$, upper stem $\left(\mathrm{US}_{\mathrm{VI}}\right)$, whole stem $\left(\mathrm{ST}_{\mathrm{VI}}=\mathrm{LS}_{\mathrm{VI}}+\mathrm{US}_{\mathrm{VI}}\right)$, branches $\left(\mathrm{BR}_{\mathrm{VI}}\right)$, crown $\left(\mathrm{CR}_{\mathrm{VI}}=\mathrm{US}_{\mathrm{VI}}+\mathrm{BR}_{\mathrm{VI}}\right)$, and tree $\left(\mathrm{TR}_{\mathrm{VI}}=\mathrm{LS}_{\mathrm{VI}}+\mathrm{US}_{\mathrm{VI}}+\mathrm{BR}_{\mathrm{VI}}\right)$
$(>500 \mathrm{~m})$ where growing conditions are more limiting than in lowland areas (Latte et al. 2015). The correlation coefficients between $A_{\mathrm{RAI}}$ and the other raw RAI series ( $B_{\mathrm{RAI}}{ }^{-}$ $J_{\text {RAI }}$ ) decreased strongly with increasing distance along the stem (Table 2). From 1930 to 2012, the volume increments of the lower stem $\left(\mathrm{LS}_{\mathrm{VI}}\right)$, upper stem $\left(\mathrm{US}_{\mathrm{VI}}\right)$ and branches $\left(\mathrm{BR}_{\mathrm{VI}}\right)$ varied from 46 to 50,42 to 30 , and 12 to $20 \%$ of $\mathrm{TR}_{\mathrm{VI}}$, respectively. $\mathrm{TR}_{\mathrm{VI}}$ was particularly low in 1990 , 1991, 1995, 1996, 2004, 2005 and 2011 (Fig. 3).

Although the number of trees was relatively small, the statistics of the detrended series ensured that the captured signal by the eight beech trees was reliable and could be used for further analysis (Table 2). The EPS values $(\geq 0.91)$ indicated that the RAI and VI detrended series were homogeneous among the selected trees. The ES values $(\geq 0.56)$ indicated that the between-tree and within-tree correlations were strong. Both, the MS and GC were quite constant among the VI detrended series but varied for the RAI detrended series, with a decrease from $1.3 \mathrm{~m}(A)$ to $9.4 \mathrm{~m}(E)$ and an increase from $12.3 \mathrm{~m}(F)$ to $23.3 \mathrm{~m}(J$; Fig. 4). Paired $t$ tests indicated that MS and GC values of $H_{\mathrm{I}}, I_{\mathrm{I}}$ and $J_{\mathrm{I}}$ are significantly different from the others RAI detrended series (supplementary material: Table B).

\section{Climate-growth analysis}

For RAI and VI detrended series, sPLS regression in association with linear regression (period 1982-2012) highlighted two climatic variables: the mean of the daily maximum temperature from July to October of the previous year (TMAX) and the sum of the daily precipitation from March to May of the current year (PREC). TMAX was slightly more explanatory than two other variables: the mean of the daily solar radiation and relative humidity of July of the previous year. The bootstrapped correlation coefficients (BCCs) between TMAX and PREC, and the detrended RAI and VI series were systematically significant, and the adjusted $R$ squares of the linear regressions ranged from 39 to $53 \%$ (Table 3 ). Concerning the ratio series, only one variable was highlighted: the mean of the daily minimum temperature from July to August of the previous year (TMIN). BCCs between this variable and the ratio series were significant for $A_{\mathrm{I}}: G_{\mathrm{I}}-J_{\mathrm{I}}, \mathrm{LS}_{\mathrm{I}}: \mathrm{US}_{\mathrm{I}}$ and $\mathrm{LS}_{\mathrm{I}}: \mathrm{CR}_{\mathrm{I}}$ (Table 3). BCCs between TMAX and PREC, TMIN and PREC and, TMAX and TMIN were -0.09 , -0.31 , and 0.79 , respectively.

\section{Pointer and discrepancy years}

In concordance with the modeling results, negative pointer years occurred the year following summer heat waves ( $\approx$ high values of TMAX and TMIN) and/or the current year in the case of spring droughts ( $\approx$ low values of PREC) 


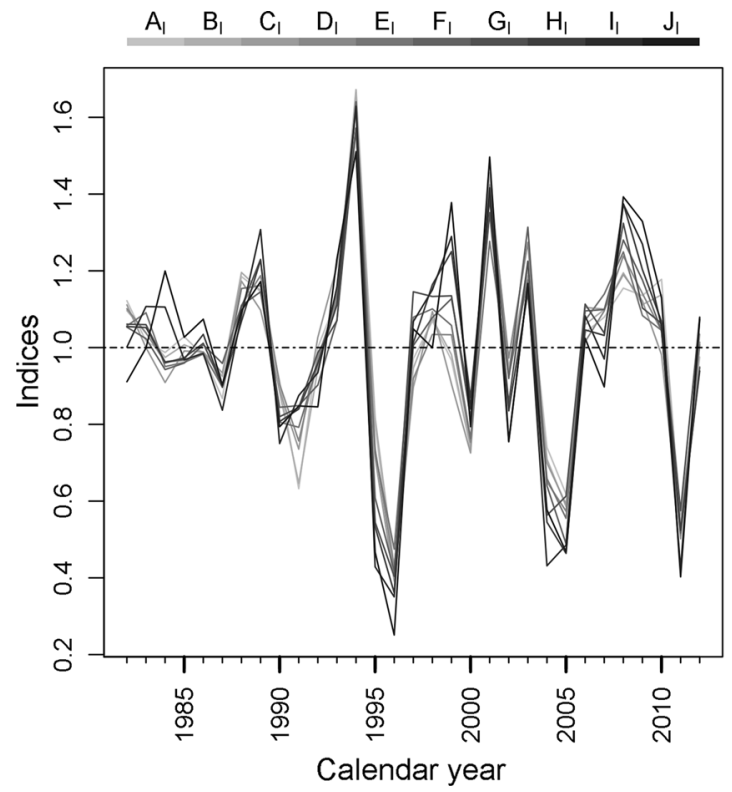

Fig. 4 Left ring-area increment (RAI) detrended series at the ten sampling heights $\left(A_{\mathrm{I}}-J_{\mathrm{I}}\right)$ for the common period 1982-2012 (average values of the eight trees). Right box plots of the mean sensitivities (MS) and Gini coefficient (GC) computed from the tree RAI

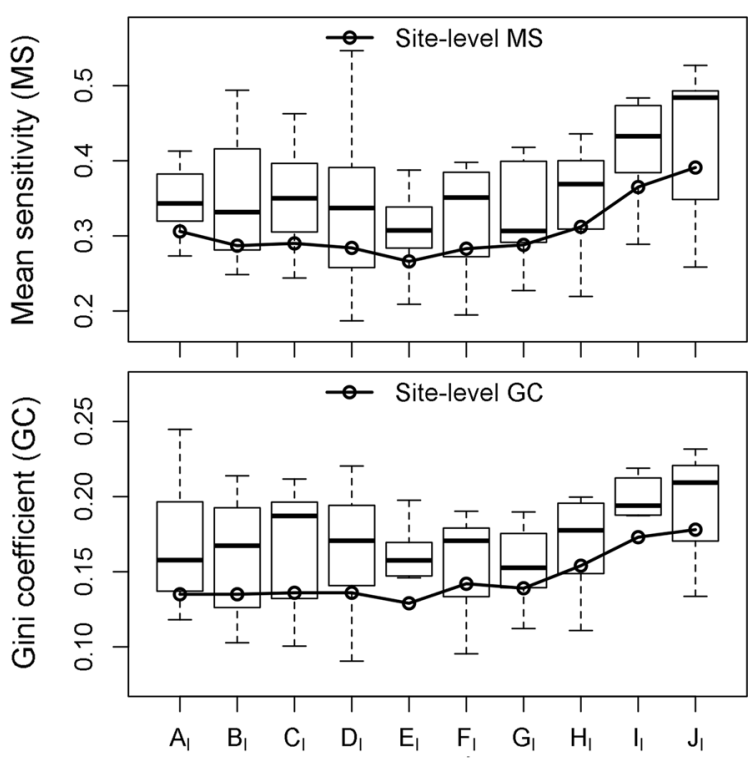

detrended series $\left(A_{\mathrm{I}}-J_{\mathrm{I}}\right)$ for the same period. The lines with circles indicate MS and GC values computed from the means of the eight tree series
Table 3 Linear models and bootstrapped correlation coefficients (BCCs) between the ring-area increment (RAI) and volume increment (VI) detrended series and, the most explanatory climatic variables (TMAX, PREC, and TMIN) for the period 1982-2012

\begin{tabular}{|c|c|c|c|c|c|c|c|c|}
\hline \multicolumn{7}{|c|}{ RAI and VI detrended series } & \multicolumn{2}{|c|}{ Ratio series } \\
\hline \multirow[t]{2}{*}{ Series } & \multicolumn{2}{|l|}{ BCCs } & \multicolumn{4}{|c|}{ Linear models } & \multirow[t]{2}{*}{ Series } & \multirow{2}{*}{$\begin{array}{l}\text { BCCs } \\
\text { TMIN }\end{array}$} \\
\hline & TMAX & PREC & Intercept & TMAX & PREC & $R$ squares (\%) & & \\
\hline \multicolumn{9}{|l|}{ RAI } \\
\hline $\mathrm{A}_{\mathrm{I}}$ & -0.50 & 0.50 & $0.997 * * *$ & $-0.118 * *$ & $0.114 * *$ & 39.4 & $\mathrm{~A}_{\mathrm{I}}: \mathrm{B}_{\mathrm{I}}$ & 0.06 \\
\hline $\mathrm{B}_{\mathrm{I}}$ & -0.50 & 0.55 & $0.998 * * *$ & $-0.120 * *$ & $0.126 * * *$ & 46.3 & & \\
\hline $\mathrm{C}_{\mathrm{I}}$ & -0.48 & 0.53 & $0.983 * * *$ & $-0.113 * *$ & $0.117 * *$ & 41.0 & $\mathrm{~A}_{\mathrm{I}}: \mathrm{C}_{\mathrm{I}}$ & 0.13 \\
\hline $\mathrm{D}_{\mathrm{I}}$ & -0.54 & 0.53 & $0.995 * * *$ & $-0.129 * *$ & $0.120 * *$ & 47.0 & $\mathrm{~A}_{\mathrm{I}}: \mathrm{D}_{\mathrm{I}}$ & 0.20 \\
\hline $\mathrm{E}_{\mathrm{I}}$ & -0.51 & 0.56 & $0.991 * * *$ & $-0.114 * *$ & $0.121 * * *$ & 47.8 & $\mathrm{~A}_{\mathrm{I}}: \mathrm{E}_{\mathrm{I}}$ & 0.09 \\
\hline $\mathrm{F}_{\mathrm{I}}$ & -0.55 & 0.54 & $0.998 * * *$ & $-0.138 * *$ & $0.128 * *$ & 49.3 & $\mathrm{~A}_{\mathrm{I}}: \mathrm{F}_{\mathrm{I}}$ & 0.29 \\
\hline $\mathrm{G}_{\mathrm{I}}$ & -0.58 & 0.53 & $1.000 * * *$ & $-0.146 * * *$ & $0.122 * * *$ & 52.8 & $\mathrm{~A}_{\mathrm{I}}: \mathrm{G}_{\mathrm{I}}$ & 0.41 \\
\hline $\mathrm{H}_{\mathrm{I}}$ & -0.58 & 0.54 & $0.996 * * *$ & $-0.158 * * *$ & $0.137 * * *$ & 53.3 & $\mathrm{~A}_{\mathrm{I}}: \mathrm{H}_{\mathrm{I}}$ & 0.43 \\
\hline $\mathrm{I}_{\mathrm{I}}$ & -0.58 & 0.53 & $1.000 * * *$ & $-0.180 * * *$ & $0.145 * *$ & 52.1 & $\mathrm{~A}_{\mathrm{I}}: \mathrm{I}_{\mathrm{I}}$ & 0.48 \\
\hline $\mathrm{J}_{\mathrm{I}}$ & -0.61 & 0.47 & $1.000 * * *$ & $-0.199 * * *$ & $0.126 * *$ & 52.4 & $\mathrm{~A}_{\mathrm{I}}: \mathrm{J}_{\mathrm{I}}$ & 0.56 \\
\hline \multicolumn{9}{|l|}{ VI } \\
\hline $\mathrm{ST}_{\mathrm{I}}$ & -0.54 & 0.55 & $1.000 * * *$ & $-0.129 * *$ & $0.120 * *$ & 48.2 & & \\
\hline $\mathrm{LS}_{\mathrm{I}}$ & -0.52 & 0.53 & $0.998 * * *$ & $-0.123 * *$ & $0.118 * *$ & 44.8 & $\mathrm{LS}_{\mathrm{I}}: \mathrm{US}_{\mathrm{I}}$ & 0.41 \\
\hline $\mathrm{US}_{\mathrm{I}}$ & -0.55 & 0.56 & $0.999 * * *$ & $-0.14 * * *$ & $0.127 * * *$ & 51.3 & & \\
\hline $\mathrm{BR}_{\mathrm{I}}$ & -0.57 & 0.55 & $1.000 * * *$ & $-0.141 * * *$ & $0.128 * * *$ & 51.4 & $\mathrm{LS}_{\mathrm{I}}: \mathrm{CR}_{\mathrm{I}}$ & 0.42 \\
\hline $\mathrm{CR}_{\mathrm{I}}$ & -0.55 & 0.56 & $1.000 * * *$ & $-0.140 * * *$ & $0.127 * * *$ & 51.3 & & \\
\hline $\mathrm{TR}_{\mathrm{I}}$ & -0.55 & 0.55 & $1.000 * * *$ & $-0.133 * * *$ & $0.123 * * *$ & 50.0 & $\mathrm{~A}_{\mathrm{I}}: \mathrm{TR}_{\mathrm{I}}$ & 0.28 \\
\hline
\end{tabular}

TMAX is the mean of the daily maximum temperature from July to October of the previous year. PREC is the sum of the daily precipitation from March to May of the current year. TMIN is the mean of the daily minimum temperature from July to August of the previous year. Bold text indicates a significant correlation. $P$ values of linear models: $* * * \leq 0.001, * * \leq 0.01$, and $* \leq 0.05$ 


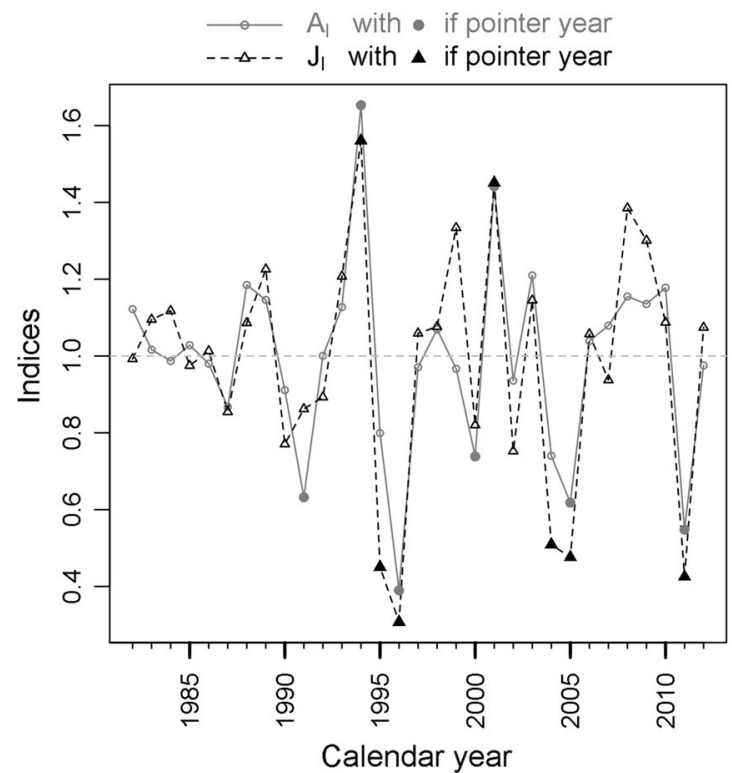

Fig. 5 Left ring-area increment (RAI) detrended series at breast height $\left(A_{\mathrm{I}}\right)$ and crown top $\left(J_{\mathrm{I}}\right)$, and corresponding pointer years for the common period 1982-2012. Right box plot of the discrepancy between $A_{\mathrm{I}}$ and $J_{\mathrm{I}}\left(\mathrm{Dy}_{A_{\mathrm{I}}: J_{\mathrm{I}}}\right)$ for the same period. Neg indicates

(supplementary material: Table C). For the common period 1982-2012, seven pointer years were highlighted at breast height $\left(A_{\mathrm{I}}\right)$ and crown top $\left(J_{\mathrm{I}}\right)$, and five of them were common to both series (two positive and three negative; Fig. 5). The highest discrepancies between $A_{\mathrm{I}}$ and $J_{\mathrm{I}}$ $\left(\mathrm{Dy}_{A_{\mathrm{I}}: J_{\mathrm{I}}}\right.$, Eq. 4) occurred during the negative pointer years ranging in average from -30 to $+52 \%$ (Fig. 5; supplementary material: Table C). No notable discrepancy $\left(-10 \% \geq \mathrm{Dy}_{\mathrm{A}_{\mathrm{I}}: J_{\mathrm{I}}} \leq+10 \%\right)$ was observed during positive pointer years. For the period 1948-2012, during which at least three cross-sections by tree compartment were available (Fig. 2), discrepancies between $\mathrm{LS}_{\mathrm{I}}$ and $\mathrm{CR}_{\mathrm{I}}$ $\left(\mathrm{Dy}_{\mathrm{LS}_{\mathrm{I}}: \mathrm{CR}_{\mathrm{I}}}\right)$ showed a very similar pattern of discrepancies but at smaller rates (from -19 to $+25 \%$ ). For the period 1930-2012, discrepancies between $A_{\mathrm{I}}$ and $\mathrm{TR}_{\mathrm{I}}\left(\mathrm{Dy}_{\mathrm{A}_{\mathrm{I}}: \mathrm{TR}_{\mathrm{I}}}\right)$ varied from -17 to $+19 \%$ (Fig. 6).

\section{Discussion}

We collected 80 stem cross-sections from eight mature beech trees (98 years old). The chronology statistics indicate that results were reliable for the considered stand that was selected to be representative of the Ardenne beech forests (Weissen et al. 1994). In accordance with other treering studies in Belgium (Kint et al. 2012; Latte et al. 2015) and elsewhere in Europe (Maxime and Hendrik 2011; Scharnweber et al. 2011; Van der Maaten 2012; Weber et al. 2013), the climate-growth analysis revealed that the

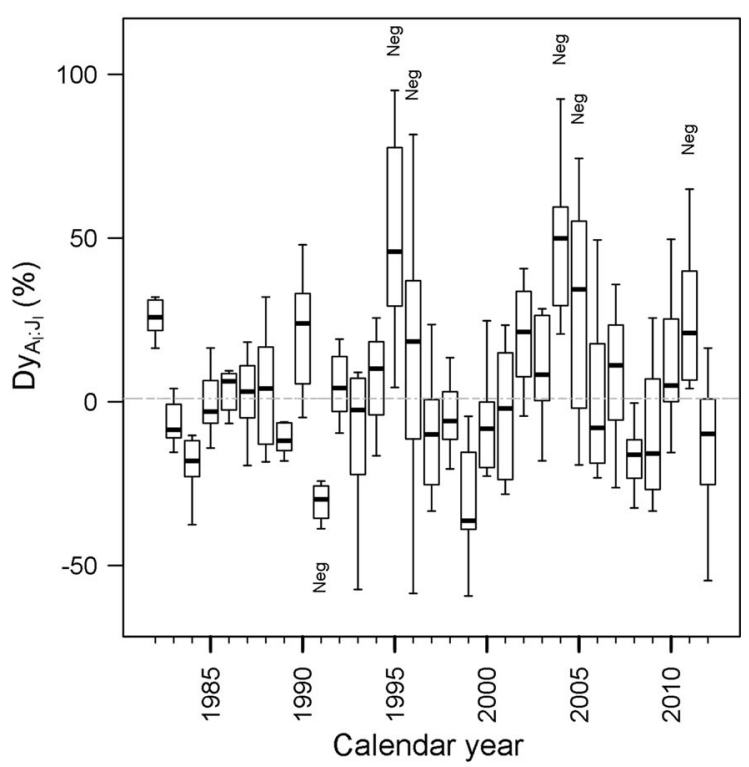

negative pointer years with notable discrepancies $\left(-10 \% \leq \mathrm{Dy}_{A_{\mathrm{I}}: J_{\mathrm{I}}} \geq 10 \%\right)$. No positive pointer year had notable discrepancies

beech growth at breast height is under a pronounced influence of climate. In combination with stem analysis, the climate-growth analysis also revealed that the growths at different heights along the main stem and of different wood compartments (crown, bole, etc.) vary rather uniformly, particularly in response to the current year's spring droughts and previous year's summer heat waves, but not at the same amplitude. Recently, in the same study region, Latte et al. (2015) reported that, since the 1980s, the negative influence of the previous year's climatic conditions has strongly increased. This study shows that, during these last decades, previous summer heat waves and related droughts indeed affected the following year's growth, but also growth partitioning within the tree.

We observed slight decreasing climate sensitivity with height in the bole (i.e., part of the stem below crow base height) in accordance with Bouriaud et al. (2005b). They performed a similar climate-growth analysis on beech at approximately $200 \mathrm{~km}$ southeast from our study site, but limited their sampling to the bole (Table 1). To our knowledge, our study provides the first report of significant increases of growth variability and climate sensitivity with height in the crown for a broadleaved species, confirming observations made on coniferous species (Kerhoulas and Kane 2012). On average, the mean sensitivity at crown top is one quarter higher than at breast height, leading to notable breast height-crown top discrepancies (up to $52 \%$ ). During negative pointer years (i.e., unusual low growth), these within-tree discrepancies amounted in 

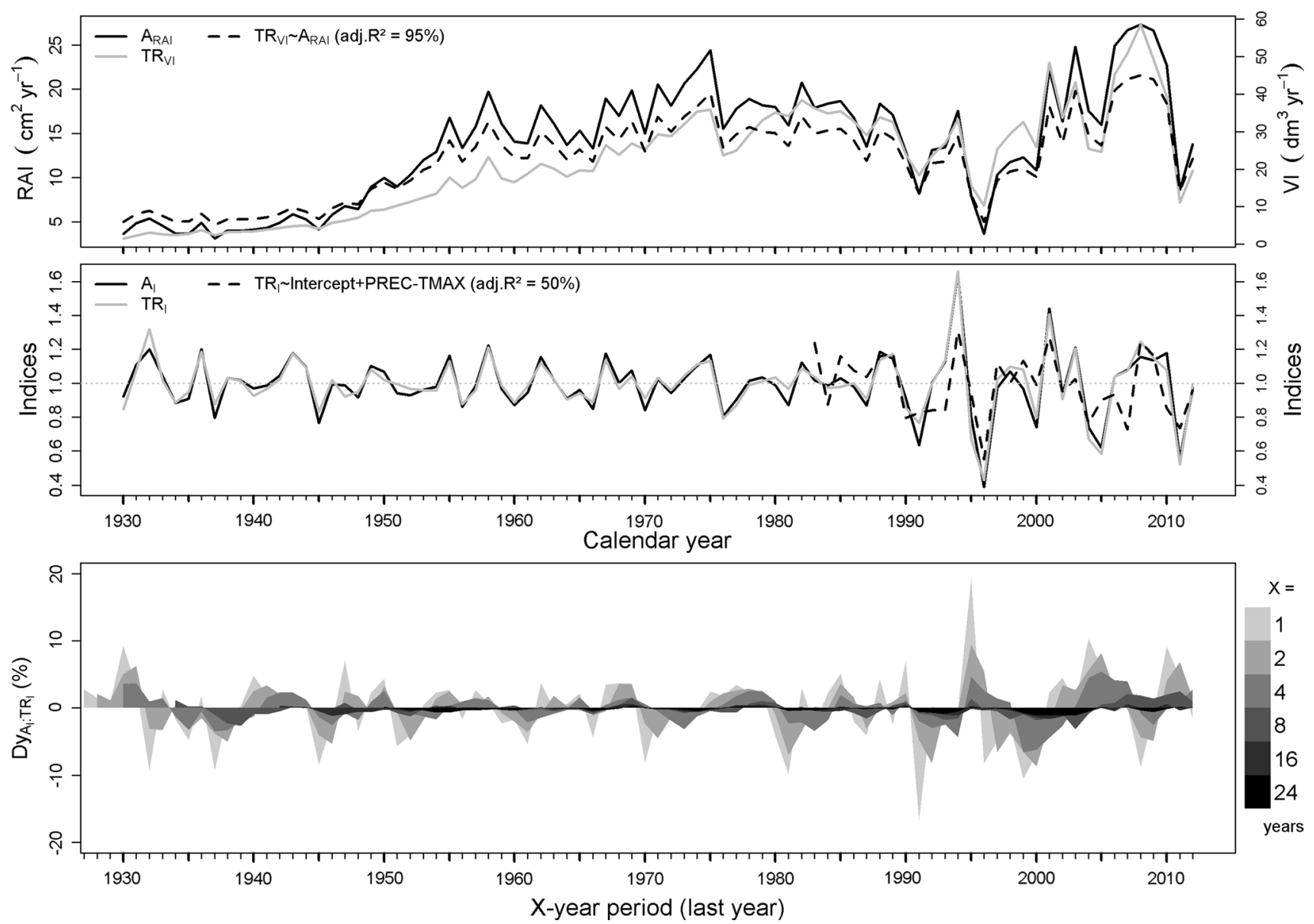

Fig. 6 The three plots refer to average values of the eight trees. Top ring-area increment (RAI) at breast height $\left(A_{\mathrm{RAI}}\right)$ and volume increment (VI) of the whole tree $\left(\mathrm{TR}_{\mathrm{VI}}\right)$ for the period 1930-2012. The dotted line corresponds to the fitted values of the linear regression between $\mathrm{TR}_{\mathrm{VI}}$ and $A_{\mathrm{RAI}}$ (without intercept). Middle the detrended series $A_{\mathrm{I}}$ and $\mathrm{TR}_{\mathrm{I}}$ for the same period. The dotted line corresponds to the fitted values of the linear regression between $\mathrm{TR}_{\mathrm{I}}$ and the most explanatory climatic variables (PREC and TMAX) for the period

average to $115 \%$ of the between-tree variation at breast height.

The overall increasing growth variability with height may be induced by increasing gravitational and hydraulic limitations (Becker et al. 2000; Kerhoulas and Kane 2012); the decreasing ratio of leaf-to-branch sapwood area with height suggests adaptations in tree structure to maintain canopy conductance (Becker et al. 2000; Gehring et al. 2015). In addition, the crown top exposure to sunlight and wind induces higher evaporation demand, and higher temperatures and daily temperature fluctuations than elsewhere in the crown and below forest canopy (Renaud et al. 2011; Von Arx et al. 2012). The respiration rate of woody tissue strongly depends on temperature, and is far higher in the upper crown than in the lower crown, with maximum values in summer (Ceschia et al. 2002; Le Goff et al. 2004). Thus, cambial physiological processes may be
1982-2012. PREC is the sum of the daily precipitation from March to May of the current year. TMAX is the mean of the daily maximum temperature from July to October of the previous year. Bottom discrepancy between $A_{\mathrm{I}}$ and $\mathrm{TR}_{\mathrm{I}}\left(\mathrm{Dy}_{A_{\mathrm{I}}: \mathrm{TR}_{\mathrm{I}}}\right)$ performed in moving windows of 1-24 years for the period 1930-2012. Darker gray indicates longer periods

affected more strongly in the crown top due to microclimate.

Despite varying climate sensitivity and growth partitioning within beech trees, the radial growth at breast height can be considered a reliable estimate for the tree volume increment (in accordance with Corona et al. 1995; Hogg et al. 2005; Rais et al. 2014). On average, the yearly differences counterbalance each other on a sufficient period (Fig. 6). Breast height-crown top discrepancies are notable but the higher sensitivity in the crown is strongly diluted at the scale of the tree. However, caution should be taken for evaluating the effects of isolated years, especially during negative pointer years. For instance in 1995, tree rings sampled at breast height would suggest a tree volume increment reduction of $-22 \%$ (compared to the previous 5 -year mean), but the actual reduction was $-38 \%$. At crown top, this reduction was $-57 \%$. Caution should also 
be taken for cumulative effects of consecutive years (e.g., 1995-1996 and 2004-2005). Using volume equations developed from DBH for estimating tree volume increments may thus result in notable underestimations, likely increasing with age, as the ratio of crown to tree volume. Moreover, the inter-annual growth variation at breast height and its climatic signal are not the most representative of the tree volume increment. It would be more accurate to use radial growth close to the crown base that has a higher correlation with the tree volume increment. Technically, coring at this sampling height is complicated, but a disk could be extracted on felled trees during forest thinning or clear-cutting. In contrast to wood sampling at breast height, there is no deprecation of the bole timber price. This possibility could thus favor tree-ring research in managed forests. As discussed by Kerhoulas and Kane (2012), the higher climate sensitivity in the crown could be used to improve precision and accuracy of dendroclimatological reconstruction. In all cases, sampling protocols should consider that, during the lifespan of a tree, the relative position of a given wood sample changes over time.

The negative effect of previous growing conditions on beech growth is usually associated with two processes. (1) The reserve depletion (Lebourgeois et al. 2005; Härdtle et al. 2013; Latte et al. 2015). Up to $20 \%$ of ring-width at breast height (Skomarkova et al. 2006) and $40 \%$ of the carbon in leaves (Dyckmans et al. 2000) come from beech reserves. (2) The trade-off between growth and fruit production (Hoch et al. 2013; Hacket-Pain et al. 2015). Summer high temperatures (Drobyshev et al. 2010; Mund et al. 2010; Hacket-Pain et al. 2015) can trigger beech masting in the following year. However, these two processes do not directly interact as beech fruit production is supplied by current photoassimilates (autonomous fruiting branches) and is thus independent of reserves (Hoch et al. 2013). No information about masting was available for the study site. However, for three mature beech stands located in the same locality, 1995, 2000, 2002, 2004 and 2011 were qualified as "heavy" mast years (period 1995-2012, data not published). Considering that the highest growth reductions and breast height-crown top discrepancies were observed in 1995, 1996, 2004, 2005 and 2011, we assume that both processes are involved. Further investigations on the underlying ecophysiological mechanisms of within-tree growth variations should ideally combine stem analysis and intra-annual analysis of wood formation, with the dynamic of non-structural carbohydrates. This combination should better disentangle effects of previous summer and current spring growing conditions on the use of reserves and new photoassimilates.

Author contribution statement NL: study design and conception, data acquisition, analysis and interpretation, and manuscript preparation and submission. FL: data analysis and interpretation, dendroecology expertise, and manuscript revision. HC: study design and supervision, data analysis and interpretation, and manuscript revision.

Acknowledgments This study was funded by the Walloon Region (Accord-Cadre de recherche et vulgarisation forestières). We would like to thank François Dewez and Philippe Louppe of the Département de la Nature et des Forêts for allowing wood sampling. We are grateful to Frédéric Henrotay and Adrien Schot (Forest Resources Management, ULg-Gembloux Agro-Bio Tech) for disk extraction, sanding, and tree-ring measurement. We also thank Yves Brostaux (Applied Statistics, Computer Science and Modeling, ULg-Gembloux Agro-Bio Tech) for his statistical support and Andrew HacketPain (Fitzwilliam College, University of Cambridge) for helpful comments and corrections to the English.

\section{Compliance with ethical standards}

Conflict of interest The authors declare that they have no conflict of interest.

\section{References}

ASCE-EWRI (2005) The ASCE Standardized Reference Evapotranspiration Equation. Environment and Water Resources Institute (EWRI) of the American Society of Civil Engineers (ASCE), Standardization of Reference Evapotranspiration Task Committee Final Report. http://www.kimberly.uidaho.edu/water/ascee wri/ascestzdetmain2005.pdf. Accessed 01 Feb 2015

Barbaroux C, Bréda N, Dufrêne E (2003) Distribution of aboveground and below-ground carbohydrate reserves in adult trees of two contrasting broad-leaved species (Quercus petraea and Fagus sylvatica). New Phytol 157:605-615

Bascietto M, Scarascia-Mugnozza G (2004) A collection of functions to determine annual tree carbon increment via stem-analysis. Ann For Sci 61:597-602

Becker P, Meinzer FC, Wullschleger SD (2000) Hydraulic limitation of tree height: a critique. Funct Ecol 14(1):4-11. doi:10.1046/j. 1365-2435.2000.00397.x

Biondi F, Qeadan F (2008) Inequality in paleorecords. Ecology 89(4):1056-1067. doi:10.1890/07-0783.1

Bouriaud O, Bréda N, Dupouey JL, Granier A (2005a) Is ring width a reliable proxy for stem-biomass increment? A case study in European beech. Can J For Res 35:2920-2933. doi:10.1139/x05202

Bouriaud O, Leban JM, Bert D, Deleuze C (2005b) Intra-annual variations in climate influence growth and wood density of Norway spruce. Tree Physiol 25:651-660

Bunn AG (2008) A dendrochronology program library in R (dplR). Dendrochronologia 26:115-124. doi:10.1016/j.dendro.2008.01. 002

Campioli M, Verbeeck H, Van den Bossche J, Wu J, Ibrom A, D'Andrea E, Matteucci G, Samson R, Steppe K, Granier A (2013) Can decision rules simulate carbon allocation for years with contrasting and extreme weather conditions? A case study for three temperate beech forests. Ecol Model 263:42-55

Carnicer J, Barbeta A, Sperlich D, Coll M, Penuelas J (2013) Contrasting trait syndromes in angiosperms and conifers are associated with different responses of tree growth to temperature on a large scale. Front Plant Sci 4:409. doi:10.3389/fpls.2013.00409

Ceschia É, Damesin C, Lebaube S, Pontailler JY, Dufrêne É (2002) Spatial and seasonal variations in stem respiration of beech trees (Fagus sylvatica). Ann For Sci 59:801-812 
Chhin S, Wang GG (2005) The effect of sampling height on dendroclimatic analysis. Dendrochronologia 23:47-55. doi:10. 1016/j.dendro.2005.07.003

Chhin S, Hogg EH, Lieffers VJ, Huang S (2010) Growth-climate relationships vary with height along the stem in lodgepole pine. Tree Physiol 30:335-345. doi:10.1093/treephys/tpp120

Cook ER, Kairiukstis LA (1990) Methods of dendrochronology: applications in the environmental sciences. Kluwer Academic Publishers, Dordrecht

Corona P, Romagnoli M, Torrini L (1995) Stem annual increments as ecobiological indicators in Turkey oak (Quercus cerris L.). Trees 10(1):13-19. doi:10.1007/bf00197774

Dagnelie P, Palm R, Rondeux J, Thill A (2013) Tables de cubage des arbres et des peuplements forestiers. Presses agronomiques de Gembloux, Gembloux

DeLucia EH, Maherali H, Carey EV (2000) Climate-driven changes in biomass allocation in pines. Glob Change Biol 6:587-593

Drobyshev I, Övergaard R, Saygin I, Niklasson M, Hickler T, Karlsson M, Sykes MT (2010) Masting behaviour and dendrochronology of European beech (Fagus sylvatica L.) in southern Sweden. For Ecol Manag 259(11):2160-2171

Dyckmans J, Flessa H, Polle A, Beese F (2000) The effect of elevated $\left[\mathrm{CO}_{2}\right]$ on uptake and allocation of $13 \mathrm{C}$ and $15 \mathrm{~N}$ in beech (Fagus sylvatica L.) during leafing. Plant Biol 2(1):113-120

Gehring E, Pezzatti GB, Krebs P, Mazzoleni S, Conedera M (2015) On the applicability of the pipe model theory on the chestnut tree (Castanea sativa Mill.). Trees Struct Funct. doi:10.1007/s00468014-1093-z

Genet H, Bréda N, Dufrêne E (2009) Age-related variation in carbon allocation at tree and stand scales in beech (Fagus sylvatica L.) and sessile oak [Quercus petraea (Matt.) Liebl.] using a chronosequence approach. Tree Physiol 30:177-192

Geßler A, Keitel C, Kreuzwieser J, Matyssek R, Seiler W, Rennenberg $\mathrm{H}$ (2007) Potential risks for European beech (Fagus sylvatica L.) in a changing climate. Trees Struct Funct 21(1):1-11. doi:10.1007/s00468-006-0107-x

Hacket-Pain AJ, Friend AD, Lageard JGA, Thomas PA (2015) The influence of masting phenomenon on growth-climate relationships in trees: explaining the influence of previous summers' climate on ring width. Tree Physiol. doi:10.1093/treephys/ tpv007

Härdtle W, Niemeyer T, Assmann T, Baiboks S, Fichtner A, Friedrich U, Lang AC, Neuwirth B, Pfister L, Ries C, Schuldt A, Simon N, von Oheimb G (2013) Long-term trends in tree-ring width and isotope signatures $(\delta 13 \mathrm{C}, \delta 15 \mathrm{~N})$ of Fagus sylvatica $\mathrm{L}$. on soils with contrasting water supply. Ecosystems 16(8):1413-1428

Hoch G, Siegwolf RTW, Keel SG, Körner C, Han Q (2013) Fruit production in three masting tree species does not rely on stored carbon reserves. Oecologia 171(3):653-662

Hogg EH, Brandt JP, Kochtubajda B (2005) Factors affecting interannual variation in growth of western Canadian aspen forests during 1951-2000. Can J For Res 35:610-622. doi:10. $1139 / \mathrm{x} 04-211$

IPCC (2012) Managing the risks of extreme events and disasters to advance climate change adaptation. In: Field CB, Barros V, Stocker TF, Qin D, Dokken DJ, Ebi KL et al (eds) A special report of Working Groups I and II of the intergovernmental panel on climate change. Cambridge University Press, Cambridge

IRM - Institut Royal Météorologique (2000) Les évènements météorologiques marquants depuis le début du 20ème siècle. http://www.meteo.be/meteo/view/fr/1078912-Evenements+mar quants+depuis+1901.html. Accessed 01 Feb 2015

Kerhoulas LP, Kane JM (2012) Sensitivity of ring growth and carbon allocation to climatic variation vary within ponderosa pine trees. Tree Physiol 32:14-23
Kint V, Aertsen W, Campioli M, Vansteenkiste D, Delcloo A, Muys B (2012) Radial growth change of temperate tree species in response to altered regional climate and air quality in the period 1901-2008. Clim Change 115:343-363. doi:10.1007/s10584012-0465-x

Latte N, Lebourgeois F, Claessens H (2015) Increased tree-growth synchronization of beech (Fagus sylvatica L.) in response to climate change in northwestern Europe. Dendrochronologia 33:69-77. doi:10.1016/j.dendro.2015.01.002

Lê Cao KA, González I, Déjean S (2009) IntegrOmics: an R package to unravel relationships between two omics datasets. Bioinformatics 25:2855-2856. doi:10.1093/bioinformatics/btp515

Le Goff N, Granier A, Ottorini JM, Peiffer M (2004) Biomass increment and carbon balance of ash (Fraxinus excelsior) trees in an experimental stand in northeastern France. Ann For Sci 61:577-588

Lebaube S, Le Goff NL, Ottorini JM, Granier A (2000) Carbon balance and tree growth in a Fagus sylvatica stand. Ann For Sci 57:49-61

Lebourgeois F, Bréda N, Ulrich E, Granier A (2005) Climate-treegrowth relationships of European beech (Fagus sylvatica L.) in the French Permanent Plot Network (RENECOFOR). Trees Struct Funct 19:385-401

Lindner M, Maroschek M, Netherer S, Kremer A, Barbati A, GarciaGonzalo J, Seidl R, Delzon S, Corona P, Kolström M, Lexer MJ, Marchetti M (2010) Climate change impacts, adaptive capacity, and vulnerability of European forest ecosystems. For Ecol Manag 259(4):698-709. doi:10.1016/j.foreco.2009.09.023

Maxime C, Hendrik D (2011) Effects of climate on diameter growth of co-occurring Fagus sylvatica and Abies alba along an altitudinal gradient. Trees Struct Funct 25:265-276

McLeod A, Xu C (2014) bestglm: Best Subset GLM. R package version 0.34. http://CRAN.R-project.org/package=bestglm. Accessed 01 Feb 2014

Mund M, Kutsch WL, Wirth C, Kahl T, Knohl A, Skomarkova MV, Schulze ED (2010) The influence of climate and fructification on the inter-annual variability of stem growth and net primary productivity in an old-growth, mixed beech forest. Tree Physiol 30(6):689-704

Muukkonen P (2007) Generalized allometric volume and biomass equations for some tree species in Europe. Eur J For Res 126:157-166

Neuwirth B, Schweingruber FH, Winiger M (2007) Spatial patterns of central European pointer years from 1901 to 1971. Dendrochronologia 24:79-89

Penninckx V, Meerts P, Herbauts J, Gruber W (1999) Ring width and element concentrations in beech (Fagus sylvatica L.) from a periurban forest in central Belgium. For Ecol Manag 113:23-33

Rais A, van de Kuilen J-W, Pretzsch H (2014) Growth reaction patterns of tree height, diameter, and volume of Douglas-fir (Pseudotsuga menziesii [Mirb.] Franco) under acute drought stress in Southern Germany. Eur J For Res 133(6):1043-1056. doi:10.1007/s10342-014-0821-7

R Core Team (2012) R: A language and environment for statistical computing. R Foundation for Statistical Computing, Vienna, Austria. ISBN 3-900051-07-0. http://www.R-project.org/

Regent Instruments Canada Inc (2009). WINDENDRO for tree-ring analysis

Renaud V, Innes JL, Dobbertin M, Rebetez M (2011) Comparison between open-site and below-canopy climatic conditions in Switzerland for different types of forests over 10 years (1998-2007). Theor Appl Climatol 105:119-127

Scharnweber T, Manthey M, Criegee C, Bauwe A, Schröder C, Wilmking M (2011) Drought matters-declining precipitation influences growth of Fagus sylvatica L. and Quercus robur L. in north-eastern Germany. For Ecol Manag 262:947-961. doi:10. 1016/j.foreco.2011.05.026 
Schober R (1995) Ertragstafeln wichtiger Baumarten. JD Sauerländer's Verlag, Frankfurt am Main

Schweingruber FH (1996) Tree rings and environment. Dendroecology. Haupt Press, Berne

Skomarkova MV, Vaganov EA, Mund M, Knohl A, Linke P, Boerner A, Schulze ED (2006) Inter-annual and seasonal variability of radial growth, wood density and carbon isotope ratios in tree rings of beech (Fagus sylvatica) growing in Germany and Italy. Trees 20(5):571-586

Sohn JA, Kohler M, Gessler A, Bauhus J (2012) Interactions of thinning and stem height on the drought response of radial stem growth and isotopic composition of Norway spruce (Picea abies). Tree Physiol 32:1199-1213

van der Maaten E (2012) Climate sensitivity of radial growth in European beech (Fagus sylvatica L.) at different aspects in southwestern Germany. Trees Struct Funct 26:777-788

van der Maaten-Theunissen M, Bouriaud O (2012) Climate-growth relationships at different stem heights in silver fir and Norway spruce. Can J For Res 42:958-969. doi:10.1093/jxb/err309

Von Arx G, Dobbertin M, Rebetez M (2012) Spatio-temporal effects of forest canopy on understory microclimate in a long-term experiment in Switzerland. Agric For Meteorol 166-167:144-155

Way DA, Oren R (2010) Differential responses to changes in growth temperature between trees from different functional groups and biomes: a review and synthesis of data. Tree Physiol 30:669-688

Weber P, Bugmann H, Pluess AR, Walthert L, Rigling A (2013) Drought response and changing mean sensitivity of European beech close to the dry distribution limit. Trees Struct Funct 27:171-181

Weissen F, Bronchart L, Piret A (1994) Guide du boisement des stations forestières de Wallonie. Ministère de la Région wallonne, Namur

Zang C, Biondi F (2013) Dendroclimatic calibration in R: the bootRes package for response and correlation function analysis. Dendrochronologia 31:68-74

Zianis D, Muukkonen P, Makipaa R, Mencuccini M (2005) Biomass and stem volume equations for tree species in Europe. Silva Fenn Monogr (4):1-2, 5-63 